\title{
DEVELOPING ENGLISH LANGUAGE SUPPORT FOR THE LINGUA FRANCA LEARNING ENVIRONMENTS AT THE MASTER'S LEVEL
}

\author{
Kari K. Pitkänen, Tuula Lehtonen, Roy Siddall, and \\ Anu Virkkunen-Fullenwider \\ University of Helsinki
}

\begin{abstract}
This paper focuses on the changing landscape of international higher education and the role language plays in the current trend towards internationalization through Englishmedium Master's Degree Programmes at the University of Helsinki. We provide an overview of the changing situation, with the increasing number of new English-medium programmes, and discuss the development of language support designed to meet the needs of the students in these programmes. This paper is based on a pilot project for developing language support for these programmes at the University of Helsinki.
\end{abstract}

Keywords: writing, language support, lingua franca learning environment, English-medium instruction

\section{Introduction}

The University of Helsinki offers, according to its strategic plans, Master's programmes taught in English. These programmes exist alongside the traditional instruction in Finnish and Swedish, the two national languages. So far, the number of international students in these programmes has been relatively small in comparison with the rest of the student population. In 2009, there were 34 international Master programmes, approximately 1500 foreign degree students and 995 exchange students at the university, while the total number of students was 35,258 (Nurro 2010). However, Maiworm and Wächter (2002: 11, 26-27) noted at the beginning of this millennium that, in relation to the size of the education system as a whole, Finland was the second largest provider of English-medium degree programmes in those European countries where English is not an official language. They also detected a clear trend in that the older and larger institutions were more likely to offer teaching in English. In 2010, this still 
seems to be the case, at least in Finland, where institutions such as the University of Helsinki are continuously developing and establishing new English-medium programmes. Especially as a result of the Bologna process, the numbers of both international students and staff members have been increasing in Helsinki and other European institutions offering higher level education (e.g. Pyykkö, Tuomi, Juurakko-Paavola, and Fiilin 2007). The more general trends of globalization, international evaluations, quality assessments and ranking lists have pushed universities to take more conscious steps towards becoming more international. The European universities have encountered additional, increasing competition in the international education markets. For example, a former Japanese Prime Minister planned to increase the number of international students in Japan to 300,000 by 2020 (Kuwamura 2009: 189).

At the University of Helsinki, this clear strategic change is explicitly stated in two relatively recent documents: The Strategic Plan for the University of Helsinki 2010-2012 (2009) and The University of Helsinki Language Policy (2007). The Strategy points out that there is clear need to increase "high-quality foreign language degree programmes and extensive study modules" for creating "an international, multicultural environment" and to support local internationalization. Based on a European-wide survey by Maiworm and Wächter (2002: 40), the main objectives of similar projects include internationalization in itself, increased mobility of students and staff, increased cooperation with other international institutions and maintenance of these networks, and an improved quality of teaching and learning. De Wit (2005: 6) gives the general emergence of competitiveness rationale in higher education as an additional reason. In general, foreign language learning in itself is not explicitly considered as a reason (Coleman 2006: 4). Ideologically, this modern internationalization is bidirectional: rather than sending students and teachers to foreign exchange programmes, as was the standard practice in the past, the new ideology encourages more active interaction by actively opening doors to international students, to programmes that have been designed to be international. This approach not only increases the interchange of ideas but makes universities better known internationally - an important value in itself during these modern times of international ranking lists used as global indicators of high quality, and as Coleman (2006: 3) notes, when 
students have become customers and universities brands. When discussing the Finnish context, we need to remember that higher education charges no tuition fees.

In Finland, offering international education relies on the practical solution of choosing a language that is spoken as widely as possible, a language such as English. Several countries that have aimed at making their tertiary education more international have faced the problem that not that many students could study in the international programmes if they were offered in languages not as widely taught elsewhere, such as Dutch, Portuguese, Finnish, Danish or Japanese (Maiworm and Wächter 2002: 45, Coleman 2006: 5, Kuwamura 2009: 194). In countries like these, international education means education in English as the lingua franca, as it is often considered the most practical tool for providing teaching to a wider audience. There are some native speakers of English among the staff, but for the majority of the teachers it is not their native language. The majority of students also appear to have studied through the medium of other languages than English before continuing their studies abroad.

Not everybody likes the current trend. The increasing amount of education provided in English is seen as a sign of hegemony, imperialism and a threat to the local culture and languages by some, at least in Finland and the Netherlands (see e.g. de Wit 2005: 6). However, as House (2003: 556) states, "languages for communication" and "languages for identification" should be kept distinct. The former is merely a tool, often based on a lingua franca, rather than another national language, and the latter the basis of one's linguistic and cultural identity, typically based on the local languages one grew up with. What is considered as the real threat is related to Coleman's (2006: 11) scenario, according to which eventually, "the world will become diglossic, with one language for local communication, culture and expression of identity, and another - English - for wider and more formal communication, especially in writing". Since English is spoken more widely as a lingua franca than as a native language (e.g. Coleman 2006: 3), it may gradually adopt the role Latin had in science and education in the past - with the main difference being in that it is still also widely used outside Academia. However, rather than relying on a geographically specified national variant of English (such as American English or British English), scientific discourse could gradually evolve towards more discipline-specific 
Englishes, each having their own specialized lexical domains and discourse conventions, no longer carrying any particular national identity. However, at the University of Helsinki, the threat this scenario poses to the local national languages, Finnish and Swedish, still appears to be remote. The continuous importance of the national languages is clearly stated in the Language Policy. So, this practical solution designed to attract more international students to Helsinki should not threaten the status of the two most widely spoken official languages, both of which remain as the language of higher education for the majority. The current number of students in English-medium Master's programmes is far too small for this, and the number of exchange students is not likely to change this balance. Moreover, for the local students, Bachelor's level education is still offered in the national languages - as are many doctoral programmes.

Our work as language teachers at the University of Helsinki Language Centre has followed this trend. This article draws on our observations, experiences and data from the English-medium programmes where we play a role. We have analyzed student papers, course feedback, and discussions with the people responsible for the programmes.

The article first describes our language support project and our target groups of students. We continue with a description of the types of support provided, and then finally draw conclusions and provide recommendations based on our experience.

\section{The Language Support Project}

The University Language Policy states that students and teachers of International Master's Degree Programmes "will be offered language support" in order to facilitate the increasing internationalization. In accordance with this policy, the University of Helsinki Language Centre established a pilot English language support project, which was based on a clear, increasing need. This paper describes the three-year language support project (20072009), designed to specifically cater for the students of these programmes. The aims of this pragmatic and pedagogically oriented project were to map the various language needs of students in English-medium Master's Programmes (and other Englishmedium instruction); respond to these needs by developing and 
testing various support systems; and after piloting, set up language support systems (project website: http://kielikeskus.helsinki.fi/ emkt/). The starting point of providing language support was initially in two earlier projects (Lehtonen et al. 1999, 2003) and information provided by professors and lecturers teaching in English. In the project described here, the focus was on the students.

\section{Target Groups}

The aim of this section is to provide an overview of the current situation and the types of students we have in the English-medium programmes.

One of the key questions for developing language support was whether (or when) those in charge of the programmes felt that their students need language support. What we initially discovered was a mismatch of optimism and reality. The original expectations were high in relation to starting level of academic language skills among international students. Namely, the criteria for language skills were mainly based on general, not academic English. (See http://www.helsinki.fi/internationalprogrammes/ masterprogrammes/language_skills.html.) However, the reality, especially with respect to academic writing, was occasionally quite far from these expectations. Furthermore, the programmes realized this relatively early. Additionally, the programmes at the university had a network within which the coordinators discussed their experiences and the new and important ideas for development spread rapidly. Also, the programmes became more conscious of the language-related issues. The popularity of our writing courses and other language support has continuously increased together with the emergence of new programmes, and a wide variety of disciplines are currently covered. (See http:// www.helsinki.fi/internationalprogrammes/subjects.html.)

In general, European students, especially from northern Europe, have relatively advanced English language skills. It often is the first foreign language they have studied in school. Partly because of this, one of the problems with the English-medium programmes in Europe has been that language issues have been taken for granted, even though studying in a foreign language is not the same as in the mother language. In many programmes of this type, both the teachers and students use English as a non- 
native language, not only in Finland but also in the other Nordic countries (see e.g. Hellekjær and Westergaard 2003: 73). Airey (2009: 108-109) has observed some interesting changes among Swedish physics undergraduates when they were taught in English. They reported problems in following the lectures and taking notes, and as a result some simply made their note-taking more mechanical or no longer took notes. Rather than asking questions during the lectures, they tended to do so afterwards. They also reported that they prepared for the classes better in advance. Thus, teaching a group like this requires more time and encouragement for the students to use English more actively and more material to be provided in advance. However, according to Airey, language was not considered as a problem. Even though the learning strategies clearly changed, language skills were taken for granted in the syllabuses. Interestingly, before stimulated recall, even the students felt that there were very few differences in following a lecture in Swedish, their native language, or in English.

Airey focused on students of physics. An additional discourse-related problem comes with the interdisciplinary programmes, where not only the language of education but also the target audience and discipline-specific discourse conventions might be different from what the students are familiar with based on their earlier studies. At the University of Helsinki, several of the English-medium programmes are interdisciplinary. A good example is the English-medium Master's Degree Programme in Bioinformatics, which combines computer science with biosciences and medicine and the students have a variety of different linguistic and cultural backgrounds.

Typically, English-medium programmes combine students with varying academic, cultural and linguistic backgrounds and with differing discipline-specific conventions - and varying language skills. These are multilingual, non-native learning environments relying on English as a lingua franca. For many students, English is a relatively new tool for studies; previous education is often completed in another language. Also, there may be some differences in the study cultures, which in the case of these programmes may still be based on the Finnish system even though the language of instruction is English. Or, with the intercultural groups, new cultural conventions may emerge which can be based on a fusion of Finnish, English and more international study cultures. 
The new programmes consist of heterogeneous groups of students with new types of needs in a new linguistic and cultural context as well as a new type of learning environment provided in English. Even though there is a great deal of individual variety, based on tentative observations on student behavior rather than real data, we could roughly categorize the students into groups that live in differing linguistic environments based on: whether they are currently studying as a native or a non-native in a country where the others are either native or non-native speakers (mono- vs. bi-directionality of the lingua franca contexts); the educational system in the students' country of origin; whether we have an individual students who differs from the others linguistically and culturally or whether these students belong to larger groups of students who share the same linguistic and cultural background and identity; the nature of their social networks (member vs. outsider vs. member of a local minority); the nature of language-specific contrastive differences; i.e. whether the language of the new environment is related or not (e.g. both are Indo-European languages with articles, prepositions, etc.); whether they have completed their previous education in English or in another language (either as a native or a non-native); and the level of this education (IB programmes, university level education.

Studying in English in a non-English speaking country as a non-native speaker is not exactly the same as studying in English-speaking countries such as Australia, Great Britain or the United States. For quite many of the international students, relatively few of whom come from the same cultural or linguistic environment, this is a truly international learning and living environment where they use English as a lingua franca for practically everything throughout their stay in Finland. Some have a Finnish- or Swedish-speaking spouse, which may - or may not - encourage them to learn one of the local languages, especially if they want to stay in Finland after the graduation. Otherwise, most of the people they communicate with also rely on English as the lingua franca. In these situations, the communication is based on "verbal acrobatics", the construction of a communicative common ground based on creativity when language skills are not sufficient. At the same time, these students' academic survival depends on high-quality English. Most of what these students do, they do in English. They go through a near complete 
language change and at the same time adapt to a variety of situations where it is not always the student who has problems with the language. Those students with a Finnish spouse or a network of friends are in a slightly better position, with local guides and cultural interpreters - and developing skills in at least one of the local languages. Potentially, this also opens possibilities to extend their studies with courses offered in Finnish. However, since the programmes do not offer - or require - studies in Finnish or Swedish, the ideology seems to be that once these students graduate they will not stay in Finland, or if they do they will be working in English language-based international environments. However, some of these students may take additional courses in Finnish - if they can fit them into their syllabuses.

There is some variety in the past language and communication studies of these students depending on their country of origin. In some, the emphasis on prior language learning may have been in understanding written and/or spoken language rather than in productive skills. Also, the access of these students to English media in their daily lives varies and in some cases can be limited or nonexistent. By contrast, in some West-European countries, where American movies and television are not dubbed, pop music, computer games and popular magazines and literature are all available in English, and the students have actually been exposed to the language throughout their lives.

Whatever the level, those individuals with no larger group of students sharing the same language may have higher social needs for constructing new social networks, and thus are likely to become verbally confident and fluent faster in English than the students speaking languages such as Chinese and Spanish, who form larger language-specific in-groups.

The larger groups of students sharing a common language resemble the first one in that there is some variation in the students' language skills, but with these students there is additional native language support clarifying whatever remains vague or unclear in a lingua franca English. This strengthens the in-group bonds, where the students can share cultural and linguistic interpretations within the network and contrast the similarities and differences with their own culture. The result is a relatively closed, diglossic community where the students do things together in their own language and study in English. In a sense, they have become minority speakers in a new multi-linguistic cultural con- 
text consisting of their own language used with the compatriots, and English used for studies in an environment where the local languages are neither of these for these students. As Maiworm and Wächter (2002: 97) noted, this does not necessarily develop their language skills.

It is interesting that, socially, the Finns studying in these programmes partly resemble the previous group. Some of them bond with other Finns in the group or already have an active, existing social network. The linguistic environment where they have grown up has included Anglo-American cultural and linguistic influences and teaching of English in most cases since they were nine years old. As a contrast, in some of the other student groups, English language studies may have begun much later. Finnish students must also have completed their language requirements for the Bachelor's degree before entering the programmes, if they have a local Bachelor's degree. The Finnish students are required to study at least two other languages, in addition to their native language, for several years. However, their past English skills are to a large extent based on the written language - and understanding - even though the productive skills have gradually developed further. In the programmes, they have new needs in active language use, both in academic writing and giving presentations.

The local students have the additional opportunity to utilize courses offered in Finnish. This also makes their studies more multi-lingual. For them, English is just one of the languages used in lectures, group discussions and papers they write in the English-medium programmes. However, it is not necessarily the only one. Individual consultation, support and guidance - as well as additional courses on the same topic - are often also available in their native languages. They also maintain their own local cultural identity throughout their studies.

Another group, close to the speakers of the local majority language (Finnish), consists of the speakers of the local minority languages. For some of these languages, especially Swedish and to some extent Estonian and Russian, the critical mass is large enough at least in Helsinki that these students can leave English to Academia and use their own languages at home or within their social networks. Many of these students speak Finnish, which gives them the same access to the local culture and society outside the university as the majority speakers have. 
One more point to be noted here is the dramatic contrastive differences in languages. Danish, German and Swedish are related to English, and speakers of these languages normally have fewer difficulties than speakers of unrelated and especially typologically different languages such as Finnish, Chinese or Japanese. Despite the backgrounds, non-native speakers of English tend to have a wide variety of practical, language-related problems, including lexical and grammatical surface-text related problems, stylistic problems (and use of spoken language), problems with writing conventions (e.g. punctuation), problems with argumentation and information structure (including cohesion and coherence), and also other types of discourse-related, often cultural problems. The students also have additional challenges in dealing with new types of target audiences and their new role as an expert, who not only summarizes the key content (as in exam answers) but reviews it more critically. A growing problem is plagiarism, which is partly due to the technology that makes copy-pasting so easy, but also uncertainty in language use and unfamiliarity with academic conventions of using sources. Depending on the previous language and communication studies, experience in actually using the language, studying in English and the other languages they speak, there is some individual variation in the extent of the remaining language problems. Some students are very fluent and write well-structured, stylistically sophisticated texts. Some have very specific individual needs in relation to just some of the issues mentioned. And then, there are students with a wider set of language and discourse related needs - regardless of their earlier education in foreign languages. This increases the level of heterogeneity in the groups.

Some of the students speak English as a vernacular and/ or they have completed their previous education in English. For these students, the learning environment remains to a large extent the same. They are fluent in spoken language, but academic writing is not necessarily accurate or stylistically adequate. These students need the same type of language support the Finnish universities tend to offer their own native speakers in Finnish and Swedish. However, since the numbers of these students are so low, they are treated like the other students, with the emphasis being more on individual consultations and feedback on their writing than a course focusing on contrastive differences. These students speak their native language in a non-native environ- 
ment. Practically all guidance and supervision is provided in English as a lingua franca, spoken by people with relatively high but varying language skills. For these students, there is a risk of Finnish influence on their language, especially in learning terms and phrases quickly translated from Finnish (calques), but also in argumentation and discourse structure. Thus, they may learn general English academic skills spiced with Finnish cultural conventions.

For the non-native speakers of English who have completed their education in English, there may be additional problems with the local non-standard language variety they rely on or the use of English as a flexible non-native lingua franca by the majority of the population. This means that the students are confident, fluent and might feel that they do not need language support. However, they may have stylistic and other problems with academic English, especially in writing. Politically, this is related to speaker identity and the value of these variants.

So, these groups face different linguistic challenges. However, what they all share is the need for language support. All these students have new functional and communicative needs in a language that in most cases is not their own.

\section{The support provided}

The language support offered to the students in the English-medium programmes was based on the results of earlier language support projects, mapping the language support needs of the students, discussions with the coordinators, professors and lecturers responsible for the programmes, piloting and testing support through pedagogically different support systems. The development of the students' language skills was observed through several papers hundreds of students submitted and the feedback on the courses was systematically collected and analyzed throughout the project.

Based on the observed needs of the students and wishes of the programmes, we decided to focus on academic writing and presentations as the main components of the language support. We arranged varying tailor-made packages for the programme, campus and faculty specific groups of students. These packages consisted of either full independent courses or shorter 
sessions integrated, for instance, into research seminars. Typically, the courses consisted of lectures, in-class tasks during the sessions, home assignments, self-assessment (needs analysis), peer feedback, teacher feedback, and individual consultation sessions aimed at either specific programmes or related groups of programmes within the same faculty or on the same campus. Initially, the courses were carefully scheduled together with the programme coordinators to fit the programme needs, i.e. when the language support would be most useful in relation to, e.g., writing-related deadlines. In addition, as the emerging programmes were provided with only a limited period of initial financial support, the needs for language support were immediate.

It should also be noted that we did not begin by testing students in these programmes but by meeting the programme coordinators. However, at the very beginning, we observed the real language-use situations and contexts in some of the Master's seminars (e.g. both in Bioinformatics and Geoinformatics) and workshops (Atmospheric-Biospheric programme at Hyytiälä Research Station) arranged within the programmes. In general, the university has specified the language requirements for its students, while the programmes have set the academic selection criteria for their students. Thus, our starting point was the development of language support for these selected groups and our support courses had to be planned before the students in some of these programmes had even come to Finland. Based on the observations and discussions with the programmes, the greatest support needs were identified for specific academic skills such as writing. The starting point was the needs of the programme itself rather than those of the students. At this point, the writing courses had to be designed based on existing courses on academic writing and past experience, especially with foreign students. With the feedback collected from the students and with a better understanding of the discipline-specific similarities and differences, the language support was then further developed during the project. Thus, the evolution and development was based on practical more than theoretical considerations. There simply was no theoretical model to be used as a basis.

The main support type consists of a 28-contact-hour course with some additional feedback on writing assignments or drafts of the Master's thesis. For practical reasons, the students in some of the programmes on the same campus were gradually merged into 
more mixed language support groups. Once tested, the same types of modules were offered to the other programme organizers.

In addition to the writing course and follow-up consultation sessions, some of the programmes were provided with additional support in forms such as feedback on other, more public presentations in the departments (e.g. presentations of the Master's project in Organic Chemistry). Some of the students were given feedback by both the content and the language teacher, especially at the beginning when the number of students in these programmes was still relatively low. As the numbers of programmes increased, but at the same time their initial intake remained relatively small, we moved towards teaching related disciples within the same faculty as mixed groups. However, whenever possible we have still tried to teach programme-specific rather than mixed groups.

In some programmes the main emphasis was more on individual feedback than on providing an academic writing course. In these programmes, the students typically had a language session integrated into the content seminar, and this session focused on the academic use of language, especially writing, followed by individual consultation sessions on writing assignments or seminar papers.

The language support has been continuously developed on the basis of the contrastive problems detected during these courses, as well as the student feedback, observations and various discussions with professors, lecturers and coordinators in these programmes. During this development, we have observed notable variety in the students' language skills, and thus a clear need for the type of language support we have provided, focusing on academic writing. Although strict university-level criteria have been implemented for the starting level of language skills, these are based on general language skills rather than academic or discipline-specific uses of English. The timing of these courses was also important, but did not always match the plans of the programmes. Occasionally, the students chose groups designed for another target audience, if the time suited them better. The students did not seem to mind as long as the disciplines were loosely related. In general, the best times for providing more or less integrated language support, especially in writing, are the beginning of the Master's programme or just before the start of the individual research project, while consultation sessions are most useful when students are actually writing their theses. 
As a result of language support courses, the students became more aware of their individual development needs - as well as of issues related to language use, rhetoric, academic style and conventions. However, the general level of language skills, especially lexical and grammatical accuracy, cannot be dramatically improved in seven weeks. Even when the students know about particular grammatical or other contrastive problems they have, they often continue producing the same types of grammatical and lexical errors a year later when they receive additional feedback on the language, argumentation and style of their thesis. Thus, the focus on developing these students' language skills has been on diagnostic support for future development needs. The basis is in the type of feedback provided and in profiling individual needs.

Two earlier projects at the University of Helsinki also focused on teachers teaching in English (Lehtonen et al. 1999, 2003). In these projects, we also extended the support to cover some issues related to teaching and supervision, especially in developing systematic evaluation criteria with language considerations. As pointed out by de Wit (2005: 11), "teaching in English requires even more attention to the international dimension of the curriculum and teaching and learning process than when the teaching is in the professor's own language." Even though the language skills of the teachers are often good, they are not usually tested in these programmes. However, some of the universities, including Helsinki, offer specific Teaching Through a Foreign Language (English) courses (Pyykkö et al. 2007).

Another important teaching-related issue is the ensuring of uniform evaluation criteria, especially in evaluating the Master's thesis, which was discussed with some of the programme organizers. Clear differences were observed among teachers in how much emphasis was placed on the quality of the language when evaluating the content of a thesis. For some, the clarity of the underlying message was enough; some required higher levels of precision, readability and argumentation. By discussing the language issues with the content teachers and comparing examples of student texts, uniform criteria were developed to enable content teachers to also consider the language in a focused and more uniform manner, and thereby avoid unequal treatment of students.

The important issue in all this is the role of language in grading the thesis. We should ask ourselves what the criteria 
should be and how correct the language of a thesis should be if it is written in English. Editors of scientific journals eventually specify the language threshold for the future publications of these students, if they pursue an academic career. They may rely on a native-speaker norm, while at the same time realizing that most of their writers and readers use English as a lingua franca. As we all know, there are currently more lingua franca speakers than natives. Should the norm, then, be discipline-specific rather than culture-specific? What about the cultural discourse conventions and more general argumentation skills or the culture-specifically determined role of the reader, level of textual explicitness and the construction of the common ground, which all matter in addition to the lexical, grammatical and stylistic correctness? In these issues, a language teacher is an important guide who can make it easier for the students to adapt to the real language requirements they may encounter later in publishing their research. Expectations and ideas of quality may differ. Some of the subject teachers may focus on content and argumentation more than language. They may even encourage the use of localized English in the form of originally Finnish style sheets and guidelines, or English with a Finnish discourse structure, without being aware of this. At the same time, some have very high expectations of how much grammatical correctness can be improved or new academic lexicon acquired in seven weeks. On the other hand, language teachers need content teachers to clarify the discipline-specific issues and content requirements.

\section{Conclusions and recommendations}

Based on a European survey of English-medium degree programmes, Maiworm and Wächter (2002: 121) state that the number of international programmes in European higher education is still marginal, and for several reasons recommend that more of these should be established in the future. In this case, we recommend that language support be seriously considered as an important part of the curriculum. In institutions with several English-medium programmes, this language support should be given on a permanent basis, even if individual programmes are not. Academic English should also be a degree requirement in order to achieve high-quality degrees. At the University of Hel- 
sinki, language support is now a permanent part of the activities provided by the Language Centre - and some of the programmes have the academic writing course either as an integral part of their Master's seminars or a separate degree requirement. With the language support, communicative skills and self-confidence have improved and the students' sensitivity to textual problems has increased. These students, coordinators and supervisors have clearly realized the importance language support and the feedback has been very positive. Moreover, the support we have provided has clearly made the students more aware of not only academic writing related conventions but also their individual developmental needs.

The development of writing skills should be integrated with the other studies so that the written assignments are real tasks read by both language and content teachers - whenever possible. The writing course should be offered relatively early in the Master's programme. Most students need additional language support when writing the actual thesis. Thus, additional language feedback on student papers should be provided in this phase. In addition, the content teachers and the language teachers should collaborate in planning the language support for discipline- or faculty-specific groups. For the content teachers it is valuable to know what type of language issues are covered and how these relate to teaching content, while the language teachers need to know more about not only the discipline-specific domains and content areas but also approaches, methodological issues and discourse conventions, including journal articles that can be considered as models, classics - or provocative. In this sense, these two should not be seen as completely independent modules of the studies, but rather components of a wider whole that develop academic professionalism.

\section{Acknowledgements}

Support for English-Medium Master's Programmes $<$ http://h27.it.helsinki.fi/emkt/team.html $>$ and English-medium Master's degree programmes: <http://www.helsinki.fi/internationalprogrammes/index.html $>$. 


\section{Addresses:}

Kari K. Pitkänen

E-mail: kari.k.pitkanen@helsinki.fi

Tuula Lehtonen

E-mail: tuula.lehtonen@helsinki.fi

Roy Siddall

E-mail: roy.siddall@helsinki.fi

Anu Virkkunen-Fullenwider

E-mail: anu.virkkunen@helsinki.fi

\section{University of Helsinki Language Centre}

P.O. Box 4 (Fabianinkatu 26)

FI-00014 University of Helsinki, Finland

\section{References}

Airey, John (2009) Science, language and literacy: case studies of learning in Swedish university physics. (Uppsala Dissertations from the Faculty of Science and Technology, 81.) Uppsala: Uppsala Universitet.

Coleman, James A. (2006) "English-medium teaching in European higher education". Language Teaching 39, 1-14.

De Wit, Hans (2005) "English as the common language in higher education: issues and challenges". In Michael Woolf, ed. I gotta use words when I talk to you: English and international education, 3-14. (EAIE occasional papers, 17.) Amsterdam: European Association for International Education.

Hellekjær, Glenn Ole and Marit R. Westergaard (2003) “An exploratory survey of content learning through English at Nordic universities". In Charles van Leeuwen and Robert Wilkinson, eds. Multilingual approaches in university education. challenges and practices, 65-79, Maastricht: Universitait Maastricht.

House, Juliane (2003) "English as a lingua franca: a threat to multilingualism?" Journal of Sociolinguistics 7, 4, 556-578.

Kuwamura, Akira (2009) "The challenges of increasing capacity and diversity in Japanese higher education through proactive recruitment strategies." Journal of Studies in International Education 13, 2, 189-202.

Lehtonen, Tuula, Pearl Lönnfors, and Anu Virkkunen-Fullenwider (1999) English or not English: that is the question! Teaching through English at the University of Helsinki. (Helsingin yliopiston Opintoasiaintoimiston julkaisuja, 18.) Helsinki: Yliopistopaino. <http://kielikeskus. helsinki.fi/emkt/publications.html>. Accessed June 28, 2011. 
Lehtonen, Tuula, Pearl Lönnfors, and Anu Virkkunen-Fullenwider (2003) "Teaching through English: a university case study". In Charles van Leeuwen and Robert Wilkinson, eds. Multilingual approaches in university education: challenges and practices, 103-117. Maastricht: Universitait Maastricht.

Maiworm, Friedhelm and Bernd Wächter, eds. (2002) English-language-taught degree programmes in European higher education: trends and success factors. (ACA Papers on International Cooperation in Education.) Bonn: Lemmens.

Nurro, Terttu, ed. (2010) University of Helsinki - key facts 2010. Helsinki: Helsinki University Print.

Pyykkö, Riitta, Ulla-Kristiina Tuomi, Taina Juurakko-Paavola, and Ullamaija Fiilin (2007) "Uutta yhteistyötä ja profiilien terävöittämistä: korkeakoulujen kielikoulutus". [New forms of collaboration and sharpening of profiles: university-level language education.] In Sari Pöyhönen and Minna-Riitta Luukka, eds. Kohti tulevaisuuden kielikoulutusta. Kielikoulutuspoliittisen projektin loppuraportti, 123-153. Jyväskylän yliopisto, soveltavan kielentutkimuksen keskus. <https:/www.jyu.fi/ hum/laitokset/solki/tutkimus/projektit/kiepo/projektin_loppuraportti/ KIEPOn_loppuraportti.pdf>. Accessed June 28, 2011.

University of Helsinki Language Policy (2007) Helsinki: Yliopistopaino. $<$ http://www.helsinki.fi/strategia/pdf/HY_kieliperiaatteet.pdf $>$. Accessed June 28, 2011.

Strategic plan for the University of Helsinki 2010-2012. (2009) Helsinki: Yliopistopaino. <http://www.helsinki.fi/tutkinnonuudistus/materiaalit/ strategia 2007-2009.pdf>. Accessed June 28, 2011.

Kokkuvõte. Kari K. Pitkänen, Tuula Lehtonen, Roy Siddall ja Anu Virkkunen-Fullenwider: Inglise keele toe arendamine lingua franca õppekeskkonna tarbeks magistriõppes. Artikkel käsitleb rahvusvahelise kõrghariduse muutuvat maastikku ning keele rolli rahvusvahelistumise suundumustes Helsingi Ülikooli ingliskeelsete magistriõppekavade näitel. Artiklis antakse ülevaade muutuvast olukorrast, kus uute ingliskeelsete õppekavade arv kasvab, ning käsitletakse inglise keele toe arendamist, mis on suunatud nende õppekavade järgi õppivate üliõpilaste vajaduste rahuldamiseks. Artikkel põhineb Helsingi Ülikooli ingliskeelsete õppekavade keeletoe arendamise katseprojektil.

Võtmesõnad: kirjutamine, keeletugi, lingua franca õppekeskkond, ingliskeelne juhendamine 